\title{
IAMJ
}

INTERNATIONAL

AYURVEDIC

MEDICAL JOURNAL

Research Article

ISSN: 23205091

Impact Factor: 5.344

\section{A CLINICAL TRIAL TO EVALUATE EFFICACY OF YASHTIMADHU CHURNA IN KHALITYA}

\section{Pooja R. Sonawane ${ }^{1}$, Sadhana A. Kulkarni²}

${ }^{1}$ PG Scholar, ${ }^{2}$ Professor \& Head;

Department of Kayachikitsa, Radhakishan Toshniwal Ayurved College, Akola, Maharashtra, India

Corresponding Author: dr.pooja.sonawane@gmail.com

\section{https://doi.org/10.46607/iamj03p4062020}

(Published online: September 2020)

Open Access

(C) International Ayurvedic Medical Journal, India 2020

Article Received: 07/09/2020 - Peer Reviewed: 26/09/2020 - Accepted for Publication: 26/09/2020

Check for updates

\begin{abstract}
Introduction: Nowadays, the world is full of glamour \& glory. The concept of beauty is gaining more \& more attention globally, which is defined on some factors, among them hair is a significant one. Because of changes in our lifestyle \& environmental conditions, a number of hair fall patients are increasing day by day. According to Ayurveda, loss of hair is termed as Khalitya. Yashtimadhu Churna is selected for study as it is a Keshya Dravya \& also easily available \& very economic. Material and Methods: In the present study 15 patients of hair fall were selected randomly \& 3 gram of Yashti Churna was given in BD dose for 1 month. Results: Yashtimadhu Churna has significant effect on reducing roughness, itching and hair fall. Discussion: Yashtimadhu is useful drug to break this pathogenesis of Khalitya as it alleviates Vata \& Pitta Doshas. Conclusion: Yashtimadhu Churna is Keshya and Rasayan hence shows significant relief in Khalitya.
\end{abstract}

Keywords: Khalitya, hairfall, Yashti Churna.

\section{INTRODUCTION}

Just like face mirrors one's health, hair too reflects health \& well-being. Hair adorns the most prominent part of the body. It has great aesthetic value $\&$ it is the crowning glory of any person. Healthy, beautiful \& attractive hairs increase the charm of the personality. In this modern era various factors like faulty hair care, 
hormonal imbalance, pollution, stress, etc. accentuate the degenerative changes seen in the hair. Increase hair fall in Ayurveda is termed as Khalitya. Khalitya is considered under Kshudra Rogas by most of the authors of classical Ayurveda text ${ }^{1}$. Acharya Charaka describes that, Tejas combining with Aniladi Doshas reach the Shira Kapala \& causes hair fall by Dahana of Roma Koopa, this is termed as 'Khalitya'. Chakrapani while commenting on these states the word 'Tejas', here denotes, Deha Ushma as well as Pitta Dosh ${ }^{2}$. According to Acharya Sushrut Vruddha Pitta along with Vata reaches Romakoopa \& cause hair fall. Where Shleshma along with Shonita causes Avarodha to channel of Romakoopa which leads to stoppage of regeneration of hair, known as Indralupta, Khalitya, Ruhya, ${ }^{3,4}$. Yashtimadhu is selected for research as it is Vatghna, Pittaghna \& Keshya Dravya as well as it is Jeevaniya \& Rasayan Dravya 5 .

Aim: To evaluate the efficacy of Yashtimadhu Churna in management of Khalitya.

\section{Objectives}

- To study the efficacy of Yashtimadhu Churna in management of Khalitya.

- To study Khalitya as described in Ayurvedic Samhita.

\section{Methodology}

A. Source of Data: Patients of hair fall attending the outpatient \& inpatient department of R.T.A. College were selected for the study randomly.

\section{B. Diagnostic Criteria}

Patients were diagnosed on the basis of following clinical features-

- Number of hairs fall per day

- Roughness of hair

- Thinning of hair

\section{Inclusion criteria}

- Patients between age group 16-60 Years.

- Patients showing s/s of Khalitya of either sex.

D. Exclusion criteria

- Patients below 16 years \& above 60 years.

- Patients with systemic diseases like HTN, DM.

- Patients with other skin diseases \& secondary infection.

Table 1: Drug Review

\begin{tabular}{|l|l|}
\hline Name & Yashtimadhu \\
\hline English name & Liquorice \\
\hline Latin name & Glycyrrhiza glabra \\
\hline Family & Leguminocea \\
\hline Chemical composition & Glycyrrhizin, Glabridin, phytoestrogen \\
\hline Ras & Madhur \\
\hline Veerya & Sheet \\
\hline Vipak & Madhur \\
\hline Action \& use & Vaat, Pitta Shamak, Jeevaneeya, Sandhaneeya, Varnya, Kanthya, Kandughna, Keshya. \\
\hline
\end{tabular}

Preparation of Yashti Churna: Mula of Yashtimadhu were dried properly \& fine powder was made \& then powder was filtered from cotton cloth \&was kept ready to consume orally ${ }^{6}$.

Table 2: Method of Administration

\begin{tabular}{|l|l|}
\hline No of patients & 15 \\
\hline Name of drug & Yashtimadhu Churna \\
\hline Drug dose & 3 gm orally \\
\hline Time of drug & Twice a day \\
\hline Anupan & Koshna Jal \\
\hline Duration & 1 month \\
\hline Follow up & 15 th \&30th day \\
\hline
\end{tabular}

\section{A. Subjective Parameters}


Table 3: a. Roughness of hair

\begin{tabular}{|l|l|}
\hline 0 & Smooth hair \\
\hline 1 & Occasionally rough \\
\hline 3 & Slight rough \\
\hline
\end{tabular}

Table 4: b. Itching at scalp

\begin{tabular}{|l|l|}
\hline 0 & No itching \\
\hline 1 & Mild \\
\hline 3 & Moderate \\
\hline
\end{tabular}

\section{B. Objective Parameter}

Table 5: a. Hair pull test

\begin{tabular}{|l|l|}
\hline 0 & $1-3$ hair \\
\hline 1 & $4-6$ hair \\
\hline 2 & $>6$ hair \\
\hline
\end{tabular}

Table 6: b. No. of hair fall per day test

\begin{tabular}{|l|l|}
\hline 0 & $<100$ \\
\hline 1 & $101-150$ \\
\hline 2 & $151-200$ \\
\hline 3 & $>200$ \\
\hline
\end{tabular}

\section{Observation}

Table 7: A. Age wise distribution of patients

\begin{tabular}{|l|l|l|l|}
\hline Sr.no & Age groups & No. of patients & Percentage \\
\hline 1 & $11-20$ & 0 & $0 \%$ \\
\hline 2 & $21-30$ & 11 & $73.33 \%$ \\
\hline 3 & $31-40$ & 1 & $6.66 \%$ \\
\hline 5 & $41-50$ & 2 & $13.33 \%$ \\
\hline 5 & $51-60$ & 1 & $6.66 \%$ \\
\hline
\end{tabular}

Table 8: B. Sex wise distribution of patients

\begin{tabular}{|l|l|l|l|}
\hline Sr. no & Sex & No. of patients & Percentage \\
\hline 1 & male & 0 & $0 \%$ \\
\hline 2 & female & 15 & $100 \%$ \\
\hline
\end{tabular}

Table 9: C. Religion wise distribution of patients

\begin{tabular}{|l|l|l|l|}
\hline Sr.no & Religion & No. of patients & Percentage \\
\hline 1 & Hindu & 12 & $80 \%$ \\
\hline 2 & Muslim & 2 & $13.33 \%$ \\
\hline 3 & Buddhist & 1 & $6.66 \%$ \\
\hline 4 & Christian & 0 & $0 \%$ \\
\hline
\end{tabular}


Table 10: D. Kesh Prakruti wise distribution of patients

\begin{tabular}{|l|l|l|l|}
\hline Sr.no & Kesh Prakruti & No. of patients & Percentage \\
\hline 1 & Vataj & 11 & $73.33 \%$ \\
\hline 2 & Pittaj & 2 & $13.33 \%$ \\
\hline 3 & Kaphaj & 2 & $13.33 \%$ \\
\hline 4 & Dwandaj & 0 & $0 \%$ \\
\hline 5 & Tridoshaj & 0 & $0 \%$ \\
\hline
\end{tabular}

Table 11: E. Occupation wise distribution of patients

\begin{tabular}{|l|l|l|l|}
\hline Sr. no & Occupation & No. of patients & Percentage \\
\hline 1 & Service class & 3 & $20 \%$ \\
\hline 2 & Business class & 0 & $0 \%$ \\
\hline 3 & Farmers & 0 & $0 \%$ \\
\hline 4 & Student & 10 & $66.66 \%$ \\
\hline 5 & Housewife & 2 & $13.33 \%$ \\
\hline
\end{tabular}

Results: Table 12: A. Roughness

\begin{tabular}{|l|l|l|l|}
\hline Relief & Upshaya & No. of patients & Percentage \\
\hline $75 \%-100 \%$ & Uttam & 2 & $13.33 \%$ \\
\hline $50 \%-<75 \%$ & Madhyam & 5 & $33.33 \%$ \\
\hline $25 \%-<50 \%$ & Heen & 3 & $20 \%$ \\
\hline $0 \%-<25 \%$ & Anupshaya & 5 & $33.33 \%$ \\
\hline
\end{tabular}

Table 13: B. Itching

\begin{tabular}{|l|l|l|l|}
\hline Relief & Upshaya & No. of Patients & Percentage \\
\hline $75 \%-100 \%$ & Uttam & 2 & $13.33 \%$ \\
\hline $50 \%-<75 \%$ & Madhyam & 4 & $26.66 \%$ \\
\hline $25 \%-<50 \%$ & Heen & 3 & $20 \%$ \\
\hline $0 \%-<25 \%$ & Anupshaya & 6 & $40 \%$ \\
\hline
\end{tabular}

Table 14: C. Hair pull test

\begin{tabular}{|l|l|l|l|}
\hline Relief & Upshaya & No. of Patients & Percentage \\
\hline $75 \%-100 \%$ & Uttam & 3 & $20 \%$ \\
\hline $50 \%-<75 \%$ & Madhyam & 4 & $26.66 \%$ \\
\hline $25 \%-<50 \%$ & Heen & 5 & $33.33 \%$ \\
\hline $0 \%-<25 \%$ & Anupshaya & 3 & $20 \%$ \\
\hline
\end{tabular}

Table 15: D. Hair fall test

\begin{tabular}{|l|l|l|l|}
\hline Relief & Upshaya & No. of Patients & Percentage \\
\hline $75 \%-100 \%$ & Uttam & 3 & $20 \%$ \\
\hline $50 \%-<75 \%$ & Madhyam & 4 & $26.66 \%$ \\
\hline $25 \%-<50 \%$ & Heen & 5 & $33.33 \%$ \\
\hline $0 \%-<25 \%$ & Anupshaya & 3 & $20 \%$ \\
\hline
\end{tabular}

Table 16: Overall Assessment

\begin{tabular}{|l|l|l|l|l|}
\hline S/S & BT & AT & Relief & Percentage \\
\hline Roughness & 32 & 17 & 15 & $46.87 \%$ \\
\hline Itching & 26 & 15 & 11 & $42.30 \%$ \\
\hline Hair pull test & 34 & 15 & 19 & $55.88 \%$ \\
\hline Hair fall test & 33 & 19 & 14 & $42.42 \%$ \\
\hline
\end{tabular}




\section{DISCUSSION}

The distribution of patients based on age factor shows that, the highest incidence $(73.33 \%)$ is seen in age group 21-30 years, which may be because people in this age group are more sensitive to hair fall. In the present study the number of females $(100 \%)$ were higher than the number of males possibly because stress plays an important role in hair fall \& females are more sensitive than males. The distribution of patients' base on religion shows that, the highest incidence $(80 \%)$ is recorded among Hindus. This possibly reflects the dominance of Hindus in the population studied in a limited area. It cannot be concluded that Hindus have more incidence of Khalitya. The distribution of patients based on 'Kesh Prakruti' shows that the highest incidence (73.33\%) is recorded among 'Vataj Kesh Prakruti'. This indicates that Vata Dosh plays an important role in causation of hair fall. In the present study the distribution of patients based on occupation shows that, the highest incidence (66.66\%) is recorded among students possibly because of faulty dietary habits \& lifestyle. In the present study $46.87 \%$ patients shows relief in roughness, $42.30 \%$ patients show relief in itching, $55.88 \%$ patients show improvement in hair pull test \& $42.42 \%$ patients shows improvement in hair fall test.

\section{Hypothetical Action of Yashtimadhu}

Yashtimadhu is Guru, Snigdha \& Madhur Rasatmak hence it alleviates Vata Dosha. Its Vipak is Madhur \& Veerya is Sheet hence it alleviates Pitta Dosha. According to Acharya Sushrut, in pathogenesis of Khalitya Vruddha Pitta, along with Vata reaches Romakoopa \& causes hair fall. Which means Vata \& Pitta Doshas plays an important role in pathogenesis of Khalitya. Yashtimadhu is useful drug to break this pathogenesis of Khalitya as it alleviates Vata \& Pitta Doshas.

\section{CONCLUSION}

Now a days Khalitya is a trending disease $\&$ it occurs due to various causes regarding diet, lifestyle, stress, various hair care products having chemicals etc. It has various aggravating factors like salty $\&$ hard water, rainy \& winter season hair dye, hair colors, etc. Yashtimadhu churna is Keshya \& Rasayan, hence when taken orally in $3 \mathrm{gm}$ in BD dose for 1 month, shows significant relief in hair fall. No side effect is recorded in the present study. Major part to avoid the occurrence of Khalitya is prevention of the cause. So, patients of Khalitya must be aware about healthy diet \& proper lifestyle.

\section{REFERENCES}

1. Sushrut, Kaviraj Ambikadatta Shastri, Sushrut Samhita, Nidansthan, Adhyay 13,3, Chaukhambha Sanskrit Prakashan,Varanasi, Reprint 2011,102.

2. Charak, Pt Kashinath Shastri, Charak Samhita, Chikitsasthan, Adhyay 26, 132, Chaukhambha Surbharti Prakashan, Varanasi, Reprint 2005,593.

3. Sushrut, Kaviraj Ambikadatta Shastri, Sushrut Samhita, Nidansthan, Adhyay 13, 32, Chaukhambha Sanskrit Prakashan, Varanasi, Reprint 2011,104.

4. Vagbhat, D R. Ganesh Garde, Vagbhat Samhita, Uttarsthan, Adhyay23,24, Chaukhambha Surbharti Prakashan, Varanasi, Reprint 2019,424.

5. Vaidya Vishnu Gogte, Dravyagun Vidnyan, Vaidya Mitra Prakashan, Pune, $1^{\text {st }}$ Edition, Reprint 2008,559.

6. Sharangdhara, Dr. Bramhanand Tripathi, Sharangdhar Samhita, Madhyam Khanda, Adhyay 6, 1, Chaukhambha Surbharti Prakashan, Varanasi, Reprint 2017, 116.

\section{Source of Support: Nil Conflict of Interest: None Declared}

How to cite this URL: Pooja R. Sonawane \& Sadhana A. Kulkarni: A Clinical Trial to Evaluate Efficacy of Yashtimadhu Churna in Khalitya. International Ayurvedic Medical Journal \{online\} 2020 \{cited September, 2020\} Available from: http://www.iamj.in/posts/images/upload/2469 2473.pdf 